DOI: https://doi.org/10.31073/mivg20180108-133

Available at: http://mivg.iwpim.com.ua/index.php/mivg/article/view/133

УДК 004.65:004.738.52

\title{
ПЕРЕДУМОВИ СТВОРЕННЯ ІНТЕРАКТИВНИХ БАЗ ДАНИХ ІННОВАЩЙНИХ РОЗРОБОК НАУКОВИХ УСТАНОВ 3 ВИКОРИСТАННЯМ ВЕБ-ТЕХНОЛОГІЙ (НА ПРИКЛАДІ ІВПІМ НААН)
}

\author{
В.В. Книш ${ }^{1}$, Т.В. Матяш ${ }^{2}$, канд. техн. наук, К.О. Диль ${ }^{3}$ \\ ${ }^{1}$ Інститут водних проблем і меліорації НААН Київ, Україна; \\ littps://orcid.org/(0)(0)-()(0)(2-3220-9883: e-mail: vlad $a$ iw pim.com.ua \\ ${ }^{2}$ Інститут водних проблем і меліорації НААН Київ, Україна; \\ littps://orcid.org/(0)(0)-(0)(03-1225-()86X: e-mail: t.v.matiash@gmail.com \\ ${ }^{3}$ Інститут водних проблем і меліорації НААН Київ, Україна; \\ https://orcid.org/0000-0001-5919-2463; e-mail: dylaiwpim.com.ua
}

Анотація. У статті проаналізовано підходи до проблем впровадження наукових розробок, теоретичні та практичні аспекти перетворення наукових розробок в інноваційно- інвестиційний продукт з метою подальиої комерціалізації за допомогою мережі Інтернет. Особливу увагу приділено інтернет-комунікаціям між наукою та виробництвом; перевагам використання портальних рімень; формуванню репозитарію типових прикладних застосувань; запровадженню науково-популярних рубрик, розрахованих на иироку нефахову аудиторію; поєднанню тематичного контенту інформаційних та інтерактивних сервісів, цео працюють в рамках єдиного веб-сайту. Наведено основні причини недосконалості функціонування сайтів наукових установ НААН, зокрема: зручність користування, недостатній рівень застосування соиіальних мереж, відсутність тематичних фотогалерей, відеофайлів, інфографіків, точо. Визначено ряд суб'єктивних та об'єктивних факторів, які гальмують прочеси формувания та передачі наукових розробок у виробництво. На прикладі Інституту водних проблем $i$ меліорації НАAН запропоновано ряд заходів з комериіалізації інноваційних наукових розробок иляхом використання засобів інтернет-маркетингу та створення структурованих веб-оріснтованих електронних баз даних (БД). До БД, окрім переліку наукових розробок запропоновано здійснювати розгорнутий опис кожсної предметної області, з якого буде зрозуміло, які в ній діють реальні об 'скти і процеси таякі задачі користувачів треба задовольняти інформачісто з иісі бази даних. Розроблено та запропоновано підхід до внутрішньої оптимізації вмісту БД иляхом поєднання суміжних рубрик та напрямів використання наукових розробок. На конкретних прикладах наведено ефективність доповнення бази даних наукових розробок блоком поиукової оптимізації для здійснення ефективних маркетингових заходів $з$ метою впровадження результатів наукових розробок.

Ключові слова: наукові розробки, інновацій, комериіалізація, база даних, представлення розробок, інтернет-маркетинг.

Постановка проблеми. Інститут водних проблем і меліорації має напрацювання та значний потенціал у сфері науки і технологій, тому актуальним $\epsilon$ питання пошуку споживачів і замовників розробленої науково-технічної продукції та виконання наукових досліджень на договірних засадах. Інформування вітчизняних та зарубіжних партнерів про наявні та перспективні наукові розробки дозволить підвищити рівень їх впровадження, налагодити довгострокові наукові та коопераційні зв язки між вченими-розробниками та представниками бізнесу.

Для активізації процесу впровадження результатів наукових розробок необхідно вирішити питання створення засобів ефективного донесення інформації про них, особливості і можливості використання. Вирішення зазна- ченого питання можливо здійснити шляхом створення електронних інтерактивних баз даних (БД) інновацій з інтуїтивно зрозумілим веб-інтерфейсом та маркетинговими заходами, у тому числі інтернет-маркетингу.

Мета досліджень - обгрунтувати передумови створення інтерактивних БД інноваційних розробок Інституту водних проблем i меліорації для ix ефективного просування та комерціалізації 3 використанням веб-технологій.

Аналіз останніх досліджень і публікацій. Дослідженню різних аспектів проблем впровадження та подальшої комерціалізації наукових розробок присвячено низку праць вітчизняних та зарубіжних вчених. Теоретичні і практичні аспекти перетворення наукових розробок в інноваційно- інвестиційний продукт дослі- 
джено С.А. Володіним. Розробкою та реалізацією стратегії інноваційної діяльності, іiі інвестиційного та ресурсного забезпечення займалися такі вітчизняні вчені-аграрії як O.I. Дацій, М.В. Зубець, О.В. Крисальний, М.Ф. Кропивко, М.Й. Малік. У роботах П.Т. Саблука та О.Г. Шпикуляка розглядається інноваційна діяльність в аграрній сфері 3 погляду інституціонального аспекту. Науковопрактичні аспекти інноваційного розвитку та трансферу технологій досліджено в роботах М.А. Хвесика, Н.М. Фонтштейн. У роботах Н.С. Вітушко, О.П. Желай, С. П. Кулицького проведено дослідження законодавчої бази 3 питань інформатизації та дотримання авторськихправвінтернет-середовищі.Новийпідхід до інтернет-медіа розглянуто в дисертації о.Є. Макарової «Научно-популярные сайты в системе СМИ: типологические и профильные особенности». Проблематикою та налагодженням комунікацій за допомогою мережі Інтернет займались такі вітчизняні та зарубіжні вчені як Лук'янець Т.I., Титоренко Г.А, Макарова Г.Л, Швальбе Х., Пасмантьє Дж., $\Phi$. Котлер. Аналіз останніх публікацій і досліджень вчених дає змогу зробити висновок про те, що в сукупності ці роботи представляють собою наукову базу сучасних підходів до взаємодії наукових організацій та підприємств на різних етапах інноваційного процесу. У той же час питання просування, впровадження та подальшої комерціалізації наукових розробок за допомогою мережі Інтернет у частині організаційно-правових та економічних аспектів потребують подальших досліджень, але на фоні скорочення рівня бюджетного фінансування фундаментальних та прикладних досліджень для більшості наукових установ ці питання стають основними для виживання і подальшого розвитку. Відсутність зв язків між наукою, освітою, бізнесом, владою та кінцевими споживачами - основна проблема комерціалізації результатів наукових розробок $[1,2]$. Перешкодами на цьому шляху виступають недостатня інформатизація процесу комерціалізації та відсутність інфраструктури. [3]. Обов"язковою складовою процесу комерціалізації інновацій $\epsilon$ створення принципово нового інтегрованого інформаційного середовища 3 метою оперативного інформування про результати наукової діяльності. Мова йде про просування інноваційної продукції Інституту за допомогою електронних баз даних (БД) та маркетингових заходів за допомогою можливостей мережі Інтернет.

Сьогодні Інтернет найпопулярніше джерело пошуку інформації, що набуло в суспіль- стві визнання авторитетного ресурсу, оскільки пошук даних у мережі зручний, простий та потребує значно менше часу, ніж інші способи пошуку необхідної інформації без допомоги електронних ресурсів. Часи, коли інтернетсайти складалися із статичного контенту (декількох cgi або java-скриптів для обробки нескладних форм), відійшли назавжди. Сучасність вимагає від сайтів значно більшої інтерактивності. Робота в цьому напрямку проводиться Національною академією наук України. Так, Програмою інформатизації НАН України [4] передбачається перехід на підтримку Єдиного науково інформаційного простору НАН України 3 використанням переважно порталів (а не сайтів) шляхом відпрацювання методології та створення типової конфігурації порталів на базі специфічних портальних рішень, в тому числі: існуючих портальних оболонок, формування репозитарію типових прикладних застосувань для компоновки порталів, а також інструментальних засобів для занурення власних прикладних напрацювань до портальної оболонки. Основною відмінністю порталу від звичайного інтернет-сайту $€$ поєднання тематичного контенту, інформаційних та інтерактивних сервісів, які працюють у рамках єдиного сайту. Ідея функціонування порталу конкретної наукової установи - охоплення тематики або галузі діяльності, що надає різні сервіси для користувачів мережі по певних інтересах. Якщо тематика порталу цікава, довкола нього формується зацікавлена «спільнота» (community) - постійна група людей, шо систематично обмінюються інформацією шляхом публікацій у тематичних блогах, обговоренні публікацій, спілкуванні на форумі чи у чаті порталу.

Результати досліджень. У більшості наукових установ Національної академії аграрних наук України та Інституті водних проблем і меліорації спостерігається недостатній рівень використання можливостей мережі Інтернет, зокрема інтерактивності, гіперпосилань, мультимедійності, експорту важливих новин у RSS та XML форматах. Про портальну представленість інформації мова поки не йде. На сайтах більшості наукових установ рідко представлені фотогалереї, інфографіки, відео, інтерактивні та анімовані засоби подання інформації. Більшість сайтів потребують покращення зручності користування (usability) та дизайну, оскільки відвідувачі залишають ресурс навіть із якісним контентом, якщо сайт незручний у користуванні. Рівень просування сайтів, а головне 
популяризації напрацювань, потребує покрашення. Робота в цьому напрямі проводиться в недостатній мірі, цікавий контент залишається поза увагою відвідувачів. Недостатнім $\epsilon$ і рівень застосування соціальних мереж, які могли б стати значним джерелом даних про результати діяльності установ для потенційних споживачів. На сайтах переважає інформація у вигляді анонсів подій, новин, заміток та статей. Рідко використовуються способи подання інформації у вигляді репортажів, версій, звітів, прогнозів, листів, інтерв ю, обговорень, опитувань та ін. $[5,6]$. Майже повністю відсутній напрямок інформування користувачів через тематичні блоги, які здатні стати ефективним середовищем для колективної діяльності, своєрідною площадкою для мозкового штурму та генерування ідей.

Незадовільний стан пояснюється низкою причин:

- не налагоджено ефективну комунікацію між науковцями та працівниками Інтернет-медіа;

- недостатня державна підтримка напрямку;

- недостатній рівень копірайтингу та наявності PR-підрозділів в установах;

- науково-популярна інформація в інтернет-медіа витіснена великим доступним потоком більш простих для розуміння і сприйняття повідомлень;

- мало уваги приділяється інтернет-маркетингу.

Перспективним напрямком $\epsilon$ запровадження на сайтах науково-популярних рубрик, розрахованих на широку нефахову аудиторію. Така інформація у значній мірі буде запозичена відомими інтернет-медіа, що збільшить цільову аудиторію. Актуальність цієї проблеми полягає в тому, що більшість вітчизняних інформаційних інтернет-ресурсів висвітлюють новини зарубіжної науки у вигляді запозичених та перекладених матеріалів. Досягнення та новини української науки фактично не висвітлюються в мережі, що призводить до недовіри суспільства до діяльності українських вчених та звинувачень у бездіяльності. Іншою важливою проблемою $€$ відсутність спільного бачення при поданні новин - інформації, наданій журналістами, бракує науковості, точності й конкретності, достовірності фактів, а матеріалам, написаним науковцями, захопливості, простоти викладу, вміння втримувати відвідувача $[7,8]$, а також наявності готових рішень і вміння описувати розробку від ідеї створення до впровадження і комерційної реалізації.
Проведений аналіз вітчизняного досвіду свідчить, що в Україні не існує зручних інтерактивних баз даних для ознайомлення, зацікавлення майбутніх споживачів 3 наявними науковими розробками. Існуючі бази даних наукових розробок установ представлені:

- у друкованому вигляді;

- у вигляді електронних каталогів 3 переліком розробок у форматі pdf:

- у вигляді переліку діючих об'єктів прав інтелектуальної власності;

- у вигляді окремого переліку 3 описом розроб̆ок на сайті конкретної наукової установи.

Такий порядок представлення наукових розробок не забезпечує високі позиції у видачі пошуковими системами та ускладнюе сприйняття інформації кінцевими користувачами, оскільки відсутня можливість зручного вибору необхідної галузі, сфери застосування, групування та поєднання результатів пошуку.

Для комерціалізації результатів наукової діяльності недостатньо надати інформацію про наукові розробки в друкованому або в друковано-електронному вигляді [9]. Необхідно проводити активні рекламні дії, які є найважливішою частиною інформаційного забезпечення ефективного просування результатів діяльності наукової установи. Неоціненну роль у цьому можуть зіграти інформаційні бази даних науково-технічних розробок зі зручним веб-інтерфейсом представлення їх вмісту. У цих базах даних має розміщуватися докладна інформація про область, особливості та можливості використання інноваційної продукції, необхідну кваліфікацію обслуговуючого персоналу, можливість і термін його навчання, приклади використання у виробничих умовах, установу розробника та авторів розробки. База даних повинна містити достатню кількість графічної, аудіо- та відеоінформації [10]. Вміст бази даних має бути відкритим для вільного доступу через мережу Інтернет. Дані про інновації в базі мають бути структуровані відповідно галузям та напрямам використання та відображати їх властивості і зв'язки між ними.

Реалізацію наведених вище підходів започатковано в Інституті водних проблем і меліорації. Так, співробітниками відділу інформаційних технологій та маркетингу інновацій розпочато створення та наповнення бази даних наукових розробок, яка представлена у вигляді веб-ресурсу для подальшої інтеграції у портальні рішення. Для проведення роботи використано локальний та фізичний підходи. Суть локального підходу полягає в поступовому нарощуванні задач, які має вирішу- 
вати веб-ресурс з БД, суть фізичного підходу полягає у створенні та фізичному розташуванні клієнт-серверної частини БД наукових розробок на серверному обладнанні Інституту.

Функції, що реалізовуються за допомогою БД і Веб розділено на три рівні: рівень представлення результатів - форми введення/надання інформації; рівень алгоpumмy - завдання i правила управління обробкою інформації (аналіз запитів, контроль даних, пошукова оптимізація,); рівень даних - архітектура та механізм зберігання даних у базі.

Окрім переліку наукових розробок запропоновано здійснювати розгорнутий опис кожної предметної області, з якого буде зрозуміло, які в ній діють реальні об "єкти і процеси та які задачі користувачів треба задовольняти інформацією $з$ цієї бази даних. Розроблено та запропоновано підхід до внутрішньої оптимізації вмісту БД шляхом поєднання суміжних рубрик та напрямів використання наукових розробок.

3 метою зручності доступу до веб-ресурсу з БД інноваційних розробок запропоновано 5 підходів до налаштування БД:

- повнота - чим точніше і повніше БД, тим ймовірніше знайти необхідну інформацію;

- оптимальна структурованість - легкість пошуку та швидкий доступ до необхідних відомостей;

- актуальність - оперативне оновлення та виключення дублювання даних;

- пошукова оптимізація (внутрішня та зовнішня) інформації, що зберігається;

- цілісність і функціональність БД.

Виконанийаналіз основних функціональних можливостей сервісів веб-статистики та аналітики (Google Analytics та Yandex Metrica) показав, що наведені сервіси дозволяють відслідковувати, за якими пошуковими запитами користувачі потрапляють на сайт, оцінити їх поведінку, глибину перегляду сторінок, час перебування на сайті. Встановлено, що від 75 до 85\% нових відвідувачів потрапляють на сайти саме завдяки пошуковим системам. Проте майже 95\% відвідувачів не заходять далі другої сторінки пошукових результатів, що свідчить про необхідність проведення пошукової оптимізації, як ключового аспекту просування товарів та послуг у мережі Інтернет. Вищих позицій по релевантним пошуковим запитам можливо досягнути завдяки щільності ключових слів та ряду специфічних та загальних релевантних термінів.

Згідно сучасного представлення теорії пошукової оптимізації, SEO (англ. search engine optimization) базується на трьох (Китах): 1. Внутрішня оптимізація (ключові слова, анкор посилань, людинозрозумілі url, мета-теги і мікророзмітка та ін.); 2. Зовнішня оптимізація (посилання і т.п.); 3. Поведінкові фактори (зручність i інтуїтивно зрозумілий інтерфейс, залучення користувачів на сайт їх утримання, читабельні тексти, відео, інтерактивність, тематичні новини).

Встановлено, що при представленні інформації наукових розробок у БД існує проблема опису як самої розробки, так і іiі предметної області, які мають легко сприйматися фахівцями 3 наповнення БД, науковцями, що пропонують свої розробки, та кінцевими користувачами. Для вирішення цієї проблеми запропоновано доповнити структуру класичної моделі представлення результатів у веб орієнтованій БД рубрикою: оптимізація пошукової видачі на рівні уявлень про предметну область застосування наукової розробки (Рис. 1).

Представлення результатів пошуку $\epsilon$ першим рівнем загального подання інформації, комплексний підхід до загального інформаційного представлення результатів роботи наукової установи досягається консолідацією зусиль для подальшої інтеграції БД наукових розробок у портальні рішення, що, у свою чергу, є вагомим кроком до створення ефективної інфраструктури просування та комерціалізації наукових розробок (Рис. 2).

У якості прикладу наведемо посилання на сторінку сайту Інституту водних проблем i меліорації igim.org.ua/?page_id=1097 (Видання наукової літератури IВПіМ). Наведену сторінку було створено у грудні 2016 р. 3 метою інформування про наукові видання Інституту, що вийшли друком. Сторінка знаходиться «у двох кліках» від головної сторінки сайту ІВПіМ (головна сторінка - видання та нормативні документи - видання наукової літератури IВПіМ). Ніяких елементів пошукової оптимізації не проводилося, інформація надавалася у форматі: назва видання, обкладинка видання у форматі jpg. авторський колектив та зміст. На початку 2018 р. контент сторінки (наукову літературу) було структуровано за роком видачі; додано елементи згортання-розгортання детальної інформації про авторський колектив та зміст кожного наукового видання; додано мета-теги та атрибути alt до зображення обкладинок; зроблено прямі посилання з сайту НААН та сайтів установ станцій та господарств мережі IВПіМ; завантажено відео про IВПіМ на відеохостінг Youtube (https://www:youtube.com/ watch? $=$ VVUNOhzmpPU) зі зворотнім поси- 

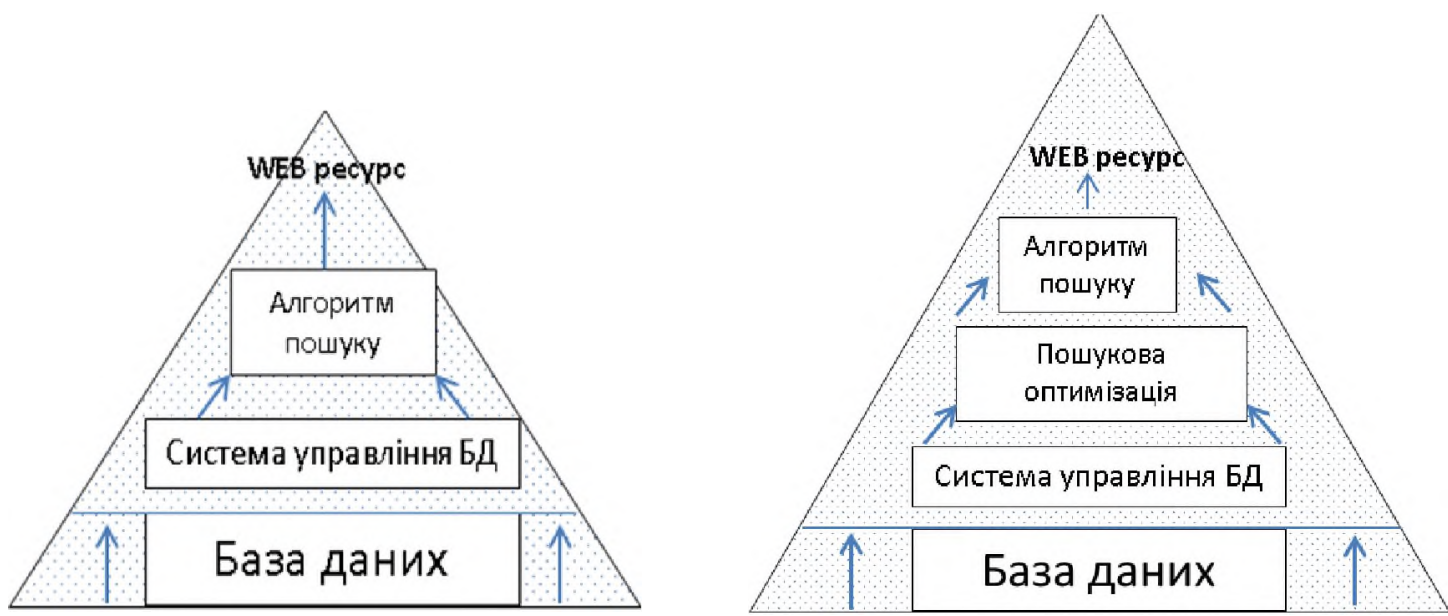

Рис. 1. Структура представлення результатів пошуку

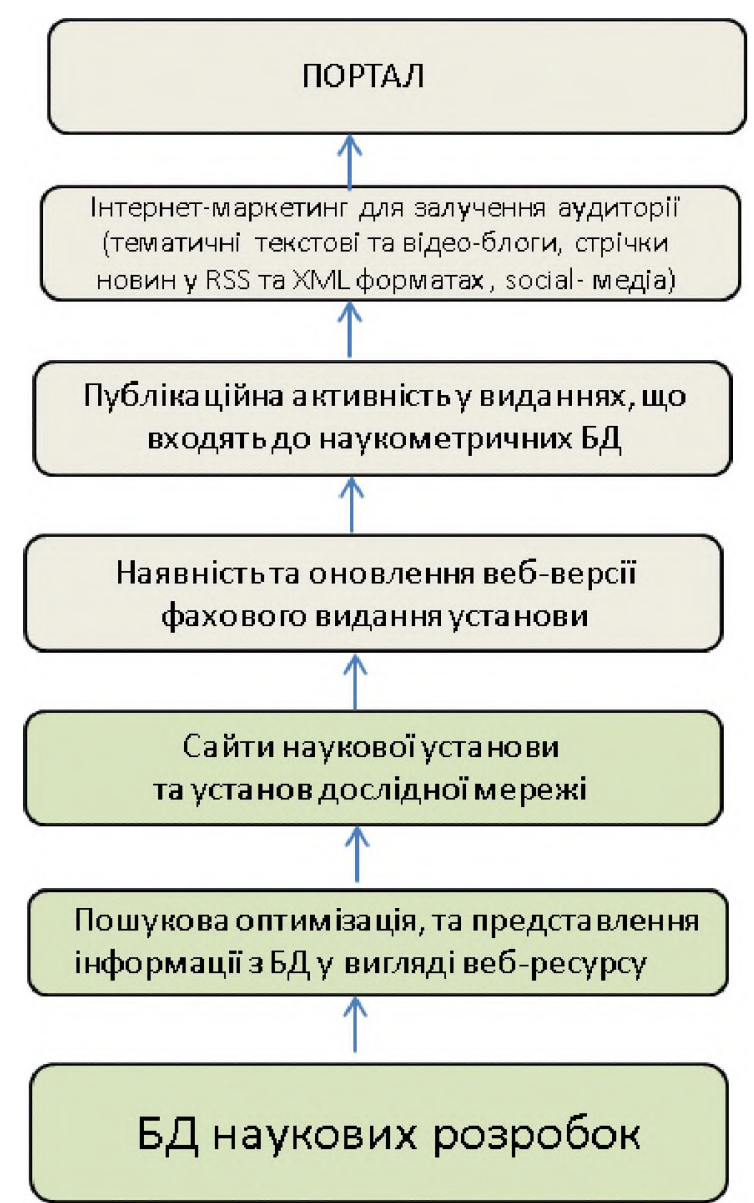

Рис. 2. Основні рівні процесу інформаційного представлення

ланням на сайт IBПіМ; оновлено інформацію про ІВПіМ на сторінці Вікіпедії; стандартний url сторінки переформатовано у людинозрозумілий. Проведені удосконалення окремої веб-сторінки (за даними сервісу Google
Analytics) дозволили збільшити відвідуваність сторінки майже у 8 разів, з 14-17 відвідувань у місяць (протягом 2017 р.) до 120-130 у місяць у 2018 р. Застосування в подальшому елементів SEO (внутрішня оптимізація, зовнішня поведін- 
кові фактори) для висвітлення інформації про наукові розробки дозволять здійснити більш успішні маркетингові заходи 3 метою впровадження у практику корисних результатів.

Висновки. Встановлено, що інформаційні технології відіграють ключову роль у процесі накопичення, поширення, ефективного використання нових знань та результатів наукових розробок. Встановлено, що на сьогодні в Україні відсутня ефективна інфраструктура представлення інформації про інноваційні та інші наукові розробки за допомогою Інтернет- комунікацій. Доведено, що проведення пошукової оптимізації $є$ ключовим засобом виведення веб-сайту в Топ-10 пошукових систем по великій кількості низькочастотних запитів. Обгрунтовано, що створення бази даних наукових розробок, яка доповнена блоком пошукової оптимізації, $\epsilon$ ядром структурованих веб-орієнтованих баз даних для подальшого здійснення ефективних маркетингових заходів за допомогою мережі Інтернет 3 метою впровадження у практику результатів наукових розробок.

\section{Бібліографія}

1. Саміло А.В. Теоретичні засади комерціалізації результатів науково-технічної діяльності державної служби України з надзвичайних ситуацій // Вісник Львівсыкого державного університету безпеки життєдіяльності. 2013. № 7. С. 285-290. URL: http://nbuv.gov.ua/UJRN/Vldubzh_2013_7_46

2. Полякова О.М. Проблеми та напрями комерціалізації наукових розробок та інноваційної продукції в Україні. // Вісник економіки транспорту і промисловості. 2016. № 54. С. 338-344.

3. Берковський В.В., Радіонов С.О. Аналіз методів створення інтерактивних web-додатків. // Системи озброєння і військова техніка. 2015. № 2 (42). С. 61-64.

4. Програма інформатизації НАН України. Концептуальні положення розвитку Програми інформатизації НАН України на 2015-2019 роки.

5. Дєдушкіна А.В. Популяризація науки в сучасному українському інтернет-просторі. // Обрії друкарства. 2015. № 1 (4). С. 39-47.

6. Дивеева Н.В. Способы и формы воздействия новых информационных технологий на популяризацию науки // RELGA: науч.-культуролог. журн., №06(279). 2014. URL: http:// www.relga.ru/Environ/WebObjects/tgu-www.woa/wa/Main?level l=main\&level2=articles\&textid=3888

7. Гусак О.О. Основні тенденції поведінки аудиторії сучасних інтернет-3МI // Вісник Книжкової палати. Київ: Кн. палата України. 2014. № 7. С. 42-45.

8. Дорофеева В.В. Проблема коммерциализации инновационных разработок предприятий Сибирского региона // Известия ИГЭА. 2010. № 5 (73). С. 57-60.

9. Мазур I. Комерціалізація наукових розробок як фактор конкурентного розвитку підприємництва // Вісник Київського національного університету імені Тараса Шевченка. 2013. № 148. URL: http://nbuv.gov.ua/UJRN/VKNU_Ekon_2013_148_3

10.Жиц Г.И., Квашнина М.Н. Коммерциализация новшеств и инновационный трансфер: некоторые подходы к трактовке понятий // Инновации. 2006. Выпуск № 11. C. 47-51. URL: http://cyberleninka.ru/article/n/kommertsializatsiya -nov shestv-i-innovatsionnyy-transfer

\section{References}

1. Samilo, A.V. (2013). Teoretychni zasady komertsializatsiyi rezul'tativ naukovo-tekhnichnoyi diyal'nosti derzhavnoyi sluzhby Ukrayiny $z$ nadzvychaynykh sytuatsiy |Theoretical bases of commercialization of the results of scientific and technical activity of the civil service of Ukraine for emergency situations|. Visnyk L'vivs'koho derzhavnoho universytetu bezpeky zhyttyediyal'nosti. 7. 285-290. Retrieved from: http://nbuv.gov.ua/UJRN/VIdubzh_2013_7_46

2. Polyakova, O.M. (2016). Problemy ta napryamy komertsializatsiyi naukovykh rozrobok ta innovatsiynoyi produktsiyi $v$ Ukrayini [Problems and directions of commercialization of scientific developments and innovative products in Ukraine]. Visnyk ekonomiky transportu i promyslovosti, $54,338-344$.

3. Berkovs'kyy, V.V., \& Radionov, S.O. (2015). Analiz metodiv stvorennya interaktyvnykh web-dodatkiv [Analysis of methods for creating interactive web-applications]. Systemy ozbroyennya i viys'kova tekhnika, 2 (42), 61-64.

4. Prohrama informatyzatsiyi NAN Ukrayiny. Kontseptual'ni polozhennya rozvytku Prohramy informatyzatsiyi NAN Ukrayiny na 2015-2019 roky [Conceptual provisions of the development of the Information Science Program of the National Academy of Sciences of Ukraine for 2015-2019].

5. Dyedushkina. A.V. (2015). Populyaryzatsiya nauky v suchasnomu ukrayins'komu internet-prostori [Popularization of science in the modern Ukrainian Internet space]. Obriyi drukarstva. 1 (4), 39-47. 
6. Diveyeva, N.V. (2014). Sposoby i formy vozdeystviya novykh informatsionnykh tekhnologiy na populyarizatsiyu nauki /Ways and forms of the impact of new information technologies on the popularization of science]. RELGA: nauch.-kul'turolog. zhurn.. 06(279), Retrieved from: http:// www.relga.ru/Environ/WebObjects/tgu-www.woa/wa/Main?levell=main\&level2=articles\&textid=3888

7. Husak. O.O. (2014). Osnovni tendentsiyi povedinky audytoriyi suchasnykh internet-ZMI |The main trends of the behavior of the audience of modern Internet media]. Visnyk Knyzhkovoyi palaty. Kyiv : Kn. palata Ukrayiny. 7. 42-45.

8. Dorofeyeva, V.V. (2010). Problema kommertsializatsii innovatsionnykh razrabotok predpriyatiy Sibirskogo regiona [The problem of the commercialization of innovative developments of enterprises of the Siberian region]. Izvestiya IGEA, 5(73), 57-60.

9. Mazur, I. (2013). Komertsializatsiya naukovykh rozrobok yak faktor konkurentnoho rozvytku pidpryyemnytstva [Commercialization of scientific developments as a factor of competitive development of entrepreneurship]. Visnyk Kyivs'koho natsional'noho universytetu imeni Tarasa Shevchenka, 148. Retrieved from: http://nbuv.gov.ua/UJRN/VKNU_Ekon_2013_148_3

10.Zhits, G.I., \& Kvashnina, M.N. (2006). Kommertsializatsiya novshestr i innovatsionnyy transfer: nekotoryye podkhody $\mathrm{k}$ traktovke ponyatiy [Commercialization of innovations and innovative transfer: some approaches to the interpretation of concepts]. Innovatsii. Vypusk, 11, 47-51. Retrieved from: http://cyberleninka.ru/article/n/kommertsializatsiya -novshestv-i-innovatsionnyy-transfer

\section{В.В. Кныш, Т.В. Матяш, К.А. Дыль Предпосылки создания интерактивных баз данных инновационных разработок научных учреждений с использованием веб-технологий (на примере ИВПиМ НААН)}

Аннотация. В статье проанализированы подходы к проблемам внедрения научных разработок, теоретические и практические аспекты преобразования научных разработок в инновационно-инвестиционный продукт с иелью дальнейщей коммерциализации с помощью сети Интернет. Особое внимание уделено интернет-коммуникачиям между наукой и производством: преимуществам использования портальных ремений: формированию репозитария типовых прикладных приложений; внедрению научно-популярных рубрик, рассчитанных на иирокую непрофессиональную аудиторию, сочетанию тематического контента информаиионных и интерактивных сервисов, работающих в рамках единого сайта. Приведены основные причины несовериенства функиионирования саитов научных учреждений НАAН, в частности: удобство пользования, недостаточный уровень использования сочиальных сетей, отсутствие тематических фотогалерей, видеофайлов, инфографиков и т.п. Определен ряд субъективных и объективных факторов, которые тормозят прочессы формирования и передачи научных разработок в производство. На примере Ннститута водных проблем и мелиорачии НААН предложен ряд мер по коммерциализачии инновационных научных разработок путем использования средств интернет-маркетинга и создания структурированных веб-ориентированных электронных баз данных (БД). К БД, кроме перечня научных разработок предложено осуществлять развернутое описание каждой предметнои области, из которого будет понятно, какие в ней действуют реальные объекты и прочессы и задачи пользователей надо удовлетворять информации из этой базы данных. Разработан и предложен подход к внутренней оптимизачии содержсимого БД путем объединения смежных рубрик и направлений использования научных разработок. На конкретных примерах показана эффективность дополнения базы данных научных разработок блоком поисковой оптимизации для осуществления эффективных маркетинговых мероприятий с иелью внедрения результатов научных разработок.

Ключевые слова: научные разработки, инновачии, коммерчиализация, база данных, представление разработок, интернет-маркетинг.

\section{Prerequisites for creating interactive databases of innovativ scientific institutions using web technologies as in the case of IWP\&LR NAAS}

Abstract. We analyze the approaches to the problems of the implementation of scientific developments. theoretical and practical aspects of the scientific developments transformation into innovative investment product in order to further commercialize through the Internet. Special attention was given to communications between science and production: the benefits of using Internet solutions; formation of a repository of typical applications; the introduction of popular science sections, designed for a wide audience; the combination between the content of information and interactive services, within a single 
website or portal. The main shortcomings in the functioning of the web-sites of scientific institutions of the NAAS were highlighted, particularly: convenience of use, social networking oriented, the lack of thematic photo galleries, video files, infographics, etc. A number of subjective and objective factors were highlighted, which inhibits the processes of formation and scientific developments transfer in production. On the example of the Institute of Water Problems and Land Reclamation of the National Academy of Sciences were proposed a series of measures for the commercialization of innovative scientific developments through the Internet marketing tools and the creation of structured web based electronic databases (DBS). To the database, in addition to the list of scientific developments. should be added a detailed description of each subject area, where it will be understood what real objects and processes are operate in it and what type of user s request could be processed. The proposed approach to the database internal content optimization - is combining adjacent rubrics and directions of the scientific developments using. Specific examples show the effectiveness of supplementing the research database with the unit of search engine optimization to provide effective marketing to implement scientific developments.

Key words: scientific developments, innovations, commercialization, database, promotion of scientific developments, Internet marketing. 